\title{
Guidance Services Availability to Student-Teachers in Colleges of Education in Volta Region, Ghana
}

\author{
Hayford Daniel Adzakpa \\ St. Francis College of Education, Hohoe \\ Department of Education Studies \\ Post Office Box 100 Hohoe Ghana
}

Seyram Dusu

Mampong Technical College of Education

Department of Education Studies

Post Office Box 31 Ashanti Mampong

Amos Amuribadek Adangabe

Nusrat Jahan Ahmadiyya College of Education, Wa

Department of Education Studies

Post Office Box71 Upper West Region

\begin{abstract}
Many students at tertiary institutions are young adults and feel more concerned about their future, getting a job and continuing higher education. Therefore, the need to provide guidance services to student-teachers to be able to overcome psycho-social, educational and career challenges that may arise during training in Colleges of Education. The purpose of this study was to find out guidance services availability to student-teachers in Colleges of Education in the Volta Region of Ghana. This study utilized a descriptive survey design. Sample of 346 respondents was selected using purposive, quota, convenience and simple random sampling techniques. Data was collected with questionnaire with reliability coefficient of 0.89.Frequency counts and percentages were used to analyse the research questions. The findings revealed that guidance services were provided to a lesser extent. Conclusions were drawn and recommendations were made based on the findings in the Colleges of Education.
\end{abstract}

Keyword: Guidance services; Colleges of Education; Availability, Student-Teachers, Guidance and Counselling.

\subsection{Introduction}

The professional field which has a broad range of activities and services aimed at assisting individuals to understand themselves, their problems, their college environment and their world is guidance and counselling (Joshua\&Esuong, 2010 and Lunenburg, 2010). To this effect guidance and counselling equips the individual through education to realise their goals, values, interests, vision and skills needed for fulfilled life. Garba (2013) is of the view that benefits of a comprehensive college counselling programme should include the promotion of vigorous academic pursuit for all students, preparation of students for challenges of adult life, relating educational programmes to future success and providing strategies for closing the achievement gap. Guidance and counselling programmes also help students to develop decision-making and problem-solving skills. According to Gumisiriza (2012), guidance and counselling services are widely known to be beneficial in shaping and decision making capabilities of both students and people at work places. Guidance and counselling is therefore essential to help remedy Student-teachers' challenges that may arise in Colleges of Education.

According to Farrant (2004), education is the total process of human learning by which knowledge is imparted, faculties trained and skills developed probably through schooling. Guidance and counselling being an integral component of education has also gone through significant transformations in the world and Ghana's educational system. Gysbers and Henderson (2001) provide a historical outlook on the development of guidance and counselling. They surmised that it was introduced during the industrial revolution in the United States of America. This was a period of rapid industrial growth, social protests, social reform and utopian idealism. Some African countries (Uganda, Malawi, South Africa and Nigeria) also have policies on guidance and counselling. For instance, the Ugandan White Paper on Education demands that career guidance and counselling should be established in all secondary schools. 
In Ghana, from the 1970s up to 2010, there has been a number of government policy statements or directives on the establishment and development of guidance and counselling programmes in the nation's educational institutions. Historically, in Ghana adults and significant individuals (traditional chiefs, family heads and religious leaders) in the Ghanaian society gave guidance in the form of advice and sharing of wisdom. This implies that the concept of guidance and counselling was not new in Ghanaian society, but as it was not formalized, practitioners are more likely to lead individuals into problems since not all wisdom fits all situations. There is a shift from the use of guidance to counselling. Guidance is the process of helping individuals to understand themselves and their world (Shertzer and Stone, 1976).To this effect, guidance helps the individuals to direct their efforts in a way that will enable them to use potentials so as to achieve personal satisfaction and thereby make themselves useful to society. According to Biswalo (1996), guidance is a term used to denote the process of helping an individual to gain selfunderstanding and self-direction (self-decision making) so that he can adjust maximally to home, colleges and community environment. The individual in this definition refers to the client, counsellee, pupils, students or Student-teachers in Colleges of Education setting where the guidance programme was offered. Guidance is the assistance given to the individuals in making intelligent choices and adjustments. It is based on the democratic principle that it is the duty and the right of every individual to choose his or her own way in life in so far as his choice does not interfere with the right of others. Guidance is the systematic professional process of helping the individual through educative and interpretive procedure to gain better understanding of his/her characteristics and potentialities and relate socially, therefore all activities are submerged under guidance.

Counselling is the process of helping an individual to accept and use information so that he can either solve his problems or cope with it successfully. According to Akinade, Sokan and Osarenren (2005), counselling is a process of helping an individual to become fully aware of himself and the ways in which he is responding to the influences of his environment. Counselling assists the individual to establish some personal meaning for his behaviour and to develop and clarify a set of goals and values for future behaviour. Therefore, counselling is the heart of the work of guidance services which is concerned with feelings, attitudes and emotional dispositions of an individual about himself and the situation facing him. Guidance and counselling has become the remedy to current challenges human beings face due to the scientific and technological development. Guidance and counselling is a process of planned intervention within a college system by which the holistic development of students are encouraged in areas relating to their personal, social, career, emotional and academic concerns.

In the Colleges of Education, even Student-teachers who feel happy and are in control of themselves have their moments of doubts and despair. Guidance and counselling will help these students prepare for life in and after tertiary education, whether or not they will get jobs, getting married and living independent and valuable life (Unachukwu\&Igborgbor, cited in Namale, 2007). Guidance services are widely known to be beneficial in shaping and decision-making capabilities of both students and people at work places. Guidance and counselling is therefore, essential to help remedy Student-teachers' challenges that may arise in Colleges of Education.Nyarko-Sampson (2010) found that the guidance services (mostly) offered in the Colleges of Education were: Orientation, Counselling, Consultation, Information, Evaluation, Placement, Appraisal and Follow-up. Orientation service is an organized group of activities through which students are given assistance to make adjustment to the school or college. (Stephenson cited in Namale, 2007). Kochhar (2006) states that counselling service is a service intended to establish a relationship between the guidance worker and the student in which the former attempts to assist the latter in achieving optimum educational, vocational, personal-social development and adjustment.According to Taylor and Buku (2006), consultation service is the aspect of guidance in which the counsellor works together with teachers, parents and other agencies to resolve the problems of students. This means seeking the help of an individual or a small group to gather useful information and suggestions to aid clients' decision making. Kankam and Onivehu (2000) opined that information service is designed to provide students with a greater knowledge of educational, vocational and personal-social opportunities so that they can make better informed choices and decisions in increasingly complex society. These definitions imply that, information service is designed to provide students with a greater knowledge on educational, vocational and social personal opportunities in order to make informed choices and decisions in an increasingly complex society. According to Taylor and Buku (2006), the purpose of placement is getting appropriate placements for students on a programme of instruction or training scheme that is in line with their plans, aptitudes, attitudes, interests, and abilities.

Placement is a selective assignment of Student-teachers or students to positions which suit their plans, interest, skills, aptitudes and physical activities. According to Numale (2007), appraisal service is mostly concerned with providing data that will highlight the individuality of each student. This means an appraisal service seeks to establish a distinctive picture of individuals by comparing them with others in terms of quantities of general human characteristics. Kochhar (2006) indicated that follow-up is the review or systematic evaluation carried out to ascertain whether guidance in general satisfies the needs of the students. This implies that clients (students/Studentteachers) are followed in order to determine the nature and extent of their needs after going through the guidance and counselling process for further assistance. 
The evaluation service completes the entire guidance and counselling process. It is essential to evaluate the use and application of guidance and counselling programme to determine its effectiveness, that is the degree to which it satisfy needs, its efficiency, how money, time and personnel are utilized (Kochhar, 2006).

According to Nyarko-Sampson (2010), there are various needs of students in educational institutions but many students are usually unable to meet their needs and they become perplexed, disappointed, confused and frustrated especially when they experience failure in their studies. Some students come to Colleges of Education as a last resort, others by influence from parents and other relations. Some still appear to be disillusioned and ignorant about the profession they are being trained for. Personally, guidance services help the individual to know and understand himself, accept his strength and weakness, and develop effective interpersonal relationships, socially balanced individual. Educationally, guidance services help the students adapt to college make educational decisions and choices by informing them about educational facilities. Guidance services help students understand their own interests, abilities and potentialities and develop them to the fullest which also helped students to identify vocational opportunities

However, in most schools, there are no systematic guidance and counselling service (GES, 2003, p.3). Empirical research findings actually corroborate the GES's observations, for instance Nyan (2014) conducted a study on students' and teachers' perception of guidance and counselling service in secondary schools in Eastern Uganda and found that students and teachers generally have a positive perception about the necessity of counselling service in secondary. According to Ackom (1992) research on guidance services at the Colleges of Education level appear to be scanty as of now, may be due to the fact that guidance itself is relatively new in Ghana. Some research studies in guidance and counselling in Colleges of Education in Ghana include: Student-teachers' appraisal of guidance and counselling programmes in Colleges of Education in Ghana: A study of selected colleges in the Eastern and Greater Accra zones (Nyarko-Sampson, 2010) which found that evaluation, placement, appraisal and follow-up service were not offered. Tutors' participations in guidance and counselling programme in Colleges of Education in Northern Ghana (Nyarko-Sampson, 2013) which concluded among other things that there is inadequate provision of guidance information materials as well as lack of accommodation to support guidance and counselling programmes.

Sedofia and Ocansey (2013) conducted a study to evaluate the information and consultation services in the Colleges of Educationin the Volta Region of Ghana. Based on their findings, it was concluded that both information and consultation services were not rendered very well to benefit students; likewise, the personnel who work as counsellors in the colleges surveyed are not professionally trained and qualified. Sedofia (2011) evaluated guidance and counselling programme in Colleges of Education in Volta Region of Ghana and found that counselling, appraisal, consultation, placement and information services were provided to a lesser extent in the colleges. The study further recognized that guidance and counselling in general was not benefiting students as it should. Mensah (2007) studied the place of guidance and counselling in Colleges of Education in the Eastern Region of Ghana and found that most college of education students did not benefit from the guidance and counselling programmes, and that some Colleges of Education had no laid down systems and structures that promoted guidance and counselling.The findings of Mensah (2007), Sedofia and Ocansey (2013) revealed that orientation, consultation, appraisal, counselling, information and placement services were offered in schools and colleges while follow-up and evaluation services were not administered. These findings of their studies go to support the fact that institutions see the need for guidance services and various attempts are made by principals, headmaster as well as teachers to institute guidance services. The purpose is to help students to make meaningful adjustment in the school situation and also to help them develop their potentialities. Aidoo (2011) conducted a study on the administration of guidance and counselling in the Colleges of Education in Ghana. The findings revealed that tutors and students rated the introduction of guidance and counselling programme as good but not satisfied with its administration therefore want an improvement. Also, orientation and counselling are the popular guidance services rendered to students in the colleges which denied them from benefiting from other guidance services. It was against this research finding that Student-teachers" perceptions of guidance services needed to be investigated in order to assist them make wise, informed and realistic decisions on their personal, social, educational and vocational choices.

Students need guidance and counselling at various levels of their educational development. Many students at tertiary institutions are young adults and feel more concerned about their future, getting a job, making a home and continuing higher education. According to Nyarko-Sampson (2010) a large number of students in Colleges of Education in Ghana find themselves in the grips of personal adjustment problems, economic problems; interpersonal problems arising from peer group influence such as smoking, problems from the opposite sex, poor self-concept, and educational problems such as inability to cope with course requirements and adjustment to institutional rules and regulations among others. These problems create tension and anxieties in students. These and many others make Student-teachers quite unfocused, leading to various misbehaviours and crises, which could be prevented with effective guidance and counselling programmes. 
However, most colleges in Ghana lack systematic guidance services. Empirical research findings actually indicate this as follows; Braimah (2010) assessed guidance and counselling services in senior high schools in the Tamale Metropolis and found that the information, appraisal, placement, evaluation, consultation and referral services were inadequately provided. Mensah (2007) studied the place of guidance and counselling inColleges of Education in the Eastern Region of Ghana and found that most college of education students did not benefit from the guidance and counselling programmes, whilst some Colleges of Education had no laid down systems and structures that promoted guidance and counselling.In evaluating guidance and counselling programmes in Colleges of Education in theEastern and Greater Accra zones, Nyarko-Sampson (2010) reported that even though guidance services exist in the colleges, Student-teachers do not patronize. The study further established that guidance services offered in the colleges were orientation, counselling, consultation and information. A study conducted by Sedofia and Ocansey (2013) to evaluate the information and consultation services in the Colleges of Education in the Volta Region ofGhana, found that the information and consultation services were not adequately provided in the colleges and the counsellors were not trained professionally. Sedofia (2011) evaluated guidance and counselling programme in Colleges of Education in Volta Region of Ghana and found that counselling, appraisal, consultation, placement and information services were provided to lesser extent in the colleges. The study further recognized that guidance and counselling in general was not benefiting students as it should. These empirical research findings reveal a gap in the review of total guidance and counselling programmes offered in the Volta Region. This phenomenon prompted the researcher to conduct this study to find out Guidance services availability to student-teachers in Colleges of Education in the Volta Region.The results of the study are expected to indicate the extent to which guidance services are administered to students in Colleges of Education in the Volta Region and its impact. The findings of the study could be useful by providing first-hand information for School Counsellors, Educators, Parents and the Ministry of Education in collaboration with Ghana Government to gain an insight into the administration of guidance services in the Colleges of Education. The study suggested measures for effective delivery of guidance services provided in Colleges of Education. Furthermore, the study provides researchers with baseline information that could be useful in future guidance research studies.

\subsection{Research Questions}

In order to achieve the purpose of the study, the following questions were formulated to guide the study.

1. What are the types of guidance services that exist in Colleges of Education in the Volta Region?

2. What reasons do Student-teachers in the college of education in the Volta Region give for not patronizing guidance services provided in their colleges?

3. What suggestion exists for the effective delivery of guidance services?

\section{Material and Methods}

\subsection{Research Design}

The study is a quantitative research and the research design adopted for the study was the descriptive survey design. According to Ary, Jacobs \& Sorensen (2010) descriptive research is a research that asks questions about the nature, incidence, or distribution of variables; it involves describing but not manipulating variables. Survey research design involves acquiring information about one or more groups of people perhaps about their characteristics, opinions, attitudes, or previous experiences by asking questions and tabulating their answers (Leedy\&Ormrod, 2005). Survey design makes it relatively easy to collect data on attitudes and opinions from large samples of subjects (Weiten, 2001) hence the suitability of the design.

\subsection{Sample and Sampling Procedure}

A sample of three hundred and forty-six (346) respondents out of the accessible population of 3,500 students was selected.

The selected sample was in accordance with Krejcie and Morgan's table (as cited in Sarantakos, 2005) determination of sample size for research activities. Krejcie and Morgan's Table of Sample Sizes (S) required for given Population Sizes $(\mathrm{N})$. The Table indicates that for a population $(\mathrm{N})$ is three thousand five hundred $(3,500)$, then sample size (S) of three hundred and forty-six (346) should be selected as sample sizes at 0.05 significant level (as cited in Sarantakos, 2005).

Purposive sampling procedure was used to select the seven colleges. Quota sampling was used to allocate percentages of the sample to each college and was used to select students from each grade level. The researchers used simple random sampling to select the first and second year students in each college to respond to the questionnaires while convenience sampling was used to select the final year students because of teaching practice. 


\section{Tables}

Table 1: Distribution of Student Population and Sample by College

\begin{tabular}{lllll}
\hline College & Population & Gender & & Sample \\
& & Male & Female & \\
\hline FRANCO & 973 & 543 & 430 & 53 \\
JASICO & 952 & 652 & 300 & 52 \\
GOVCO & 846 & 500 & 346 & 50 \\
DATCO & 775 & 425 & 350 & 49 \\
AMECO & 769 & 439 & 330 & 48 \\
TERESCO & 755 & 0 & 755 & 47 \\
AKATSICO & 755 & 420 & 335 & 47 \\
\hline Total & 5825 & 2979 & 2846 & 346 \\
\hline
\end{tabular}

Source: Student registers of AMECO, FRANCO, JASICO, TERESCO, GOVCO, DACE and AKATSICO for 2015/2016 academic year.

\subsection{Data Collection Instruments}

Questionnaire was used to collect data which comprised 37 items categorized into three sections A-C. The questionnaire was self-developed. The choice of questionnaire was based on the fact that the respondents are literates and can respond to the items independently. Section A requested the respondents' biographic data, Section $\mathrm{B}$ measured the extent to which the respondents agree to statements made on types of guidance services provided. The Section B statements/items were constructed in a 4-Point Likert Type Scale. The Likert scaling is most frequently and appropriately applied to attitude, opinions and beliefs scaling technique in educational research (UNESCO, 2005). Section C requested short responses on the patronage and effective delivery of guidance services.

The reliability measure established for the instrument was internal consistency through a pre-test. The reliability coefficient of the instrument was 0.87 alpha. This was estimated using the Cronbach's Alpha Coefficient index generated by SPSS application.

Content validity measure was adopted for the study. The instrument was discussed with the

Supervisors, who are experts in the field of guidance and counselling and one expert in the field of measurement and evaluation for scrutiny, review and judgment of its appropriateness, the researcher incorporated the necessary suggestion and corrections on the instrument and pilot-tested.

\subsection{Data Collection Procedure}

The researchers obtained ethical approval from the Institutional Review Board, before embarking on the study. In order to secure the approval of the research participants, the researchers first sought and secured introductory letter from the Department of Educational Foundations. The introductory letter was used to ask permission from the principals, counsellor and Student-teachers of various Colleges of Education for approval before embarking on the study. All parties were provided with brief, clear, concise and precise information on the research in other to get the permission required to execute the study.

The questionnaire forms were administered to the respondents by the researchers and a research assistant. The selected students assembled in their respective lecture hall where the students were made to read through the questionnaires, after they were briefed, and allowed to seek clarification on issues they do not understand. The completed forms were collected on the same day. This helped to achieve a high return rate (99\%) of the instrument.

\subsection{Data Processing and Analysis}

The analysis and interpretation of research questions were analysed using frequency counts and percentages. The researcher sorted, edited, coded and classified the open-ended questions in section ' $\mathrm{C}$ ' on the questionnaire according to the various categories of responses. Thereafter, tallied, and changed the results into percentages which were analysed according to the degree of the responses.

\section{Results}

\subsection{Types of Guidance Services available to Student-teachers}


Table 2 indicates Student-teachers'responses on the types of guidance services that exist in Colleges of Education, majority of the respondents $332(96 \%)$ agreed that orientation service exist in their colleges and $267(77.2 \%)$ Student-teachers responded that counselling service exist in their college. However, majority of $213(61.6 \%)$ Student-teachers responded that placement service does not exist in their college. Likewise, on the existence of consultation service and information service, Student-teachers of $228(65.9 \%)$ and $213(61.5 \%)$ responded respectively to disagreed that these services exist in their college.Similarly, appraisal service 201 (60.1\%), evaluation service $232(67 \%)$ and follow-up service $211(61 \%)$ were also found not existing in the colleges.

Table 2: Student-teachers' responses on the types of guidance services that exist in their Colleges of Education

\begin{tabular}{lllllllll}
\hline Guidance Services & SD & \multicolumn{3}{c}{ D } & & A & \multicolumn{3}{c}{ SA } \\
& Freq & $\%$ & Freq & $\%$ & Freq & $\%$ & Freq & $\%$ \\
\hline Orientation Service & 7 & 2.0 & 7 & 2.0 & 84 & 24.3 & 248 & 71.7 \\
Counselling Service & 36 & 10.4 & 43 & 12.4 & 185 & 53.5 & 82 & 23.7 \\
Placement Service & 121 & 35.0 & 92 & 26.6 & 89 & 25.7 & 44 & 12.7 \\
Consultation Service & 132 & 38.2 & 96 & 27.7 & 75 & 21.7 & 43 & 12.4 \\
Information Service & 126 & 36.4 & 87 & 25.1 & 98 & 28.3 & 35 & 10.1 \\
Appraisal Service & 116 & 33.5 & 92 & 26.6 & 85 & 24.6 & 53 & 15.3 \\
Evaluation Service & 105 & 30.3 & 127 & 36.7 & 100 & 28.9 & 14 & 4.0 \\
Follow-up Service & 119 & 34.4 & 92 & 26.6 & 85 & 24.6 & 50 & 14.5 \\
\hline
\end{tabular}

$\mathrm{N}=346$

\subsection{Student-teachers Reasons for not Patronizing Guidance Services}

Table 3 result shows that majority of respondents 124 (35.8\%) indicated that they do not patronize guidance services due to lack of confidentiality, followed by $62(17.9 \%)$ respondents who stated lack of guidance and counselling office, $50(14.5 \%)$ indicate lack of interest on their part of trainees, $41(11.8 \%)$ point out inadequate information about guidance services. In addition $30(8.7 \%)$ declared lack of qualified counsellor is the reason for not patronizing guidance and counselling, 21 (6.1\%) affirmed insufficient time for counselling while 18 (5.2\%) stated material resources.

Table 3: Reasons for Student-teachers' not Patronizing Guidance Services

\begin{tabular}{lll}
\hline Reasons for not Patronizing & Frequency & Percentages \\
\hline Lack of guidance and counselling office & 62 & 17.9 \\
Lack of confidentiality & 124 & 35.8 \\
Lack of material resources & 18 & 5.2 \\
Insufficient time for counselling & 21 & 6.1 \\
Lack of interest & 50 & 14.5 \\
Inadequate education & 41 & 11.8 \\
Lack of qualified counsellor & 30 & 8.7 \\
\hline Total & 346 & 100 \\
\hline
\end{tabular}

\subsection{Suggestion for the Effective Delivery of Guidance Services}

Data from Table 4 indicate that 96 respondents representing $27.7 \%$ suggested the provision of guidance and counselling office to help improve effective delivery of guidance services in Colleges of Education in Volta Region, 56 respondents representing 16.2\% suggested that counsellors must be confidential, 55 respondents representing $15.9 \%$ recommended the provision of qualified counsellors, 49 respondents representing $14.2 \%$ recommended the creation of adequate awareness on guidance and counselling activities. 
Whilst 44 respondents representing $12.7 \%$ suggested provision of material resources in guidance and counselling office, 34 respondents representing $9.8 \%$ suggested to counsellors to employ techniques to arouse Student-teachers interest and 12 representing 3.5\% recommended allocation of adequate time for guidance and counselling activities.

Table 4: Suggestions on improvement of guidance services

\begin{tabular}{lll}
\hline Suggestions & Frequency & Percentage \\
\hline Provide guidance and counselling office & 96 & 27.7 \\
Counsellors must be confidential & 56 & 16.2 \\
Provide material resources & 44 & 12.7 \\
Allocate adequate time & 12 & 3.5 \\
Employ techniques to arouse interest & 34 & 9.8 \\
Create adequate awareness & 49 & 14.2 \\
Provide qualified counsellor & 55 & 15.9 \\
\hline Total & 346 & 100 \\
\hline
\end{tabular}

\section{Discussion}

\subsection{Types of Guidance Services available to student teachers}

The findings of the study revealed that, orientation service and counselling service were provided in Colleges of Education in Volta Region hence Student-teachers are able to adjust favourably to the college environment. This agreed with Nyarko-Sampson (2010) finding that orientation and counselling are the common guidance services provided to students in Colleges of Education in Ghana. However, placement service, consultation service, information service, appraisal service, evaluation service and follow-up service were provided to a lesser extent in the colleges.

This denied the counsellor from exchanging ideas among significant individuals with the aim of helping Studentteachers.According to Taylor and Buku (2006), consultation service is the aspect of guidance in which the counsellor works together with teachers, parents and other agencies to resolve the problems of students. This means seeking the help of an individual or a small group to gather useful information and suggestions to aid clients' decision making is lacking in the college of education.

The lack of information service in the college of education deprived students of greater knowledge of educational, vocational and personal-social opportunities. Student-teachers find it difficult to choose and make use of opportunities available within the school or outside the school due to non-existence of placement services.

Appraisal and evaluation services providing data that will highlight the individuality of each student while evaluation is carried out to ascertain whether guidance in general satisfies the needs of the students were absent in the college of education.This finding confirmed Sedofia (2011) findings that appraisal, consultation, placement and information services were provided to a lesser extent in the Colleges of Education in Volta Region. This finding further agreed with Braimah(2010), Braimah assessed guidance services in senior high schools in the Tamale Metropolis and found that the counselling and orientation service were the most popular services that were offered to students while information, appraisal, placement, evaluation, consultation and referral services were inadequately provided.

\subsection{Student-teachers Reasons for not Patronizing Guidance Services}

The finding indicated majority affirmation that lack of confidentiality is the major reason why Student-teachers do not patronized guidance services. This situation is alarming in the Colleges of Education in the Volta Region due to unprofessional members of staff appointed as counsellors who do not have in-depth knowledge in the guidance and counselling profession. However, Student-teachers have challenges ranging from personal, social and educational which requires the services of the counsellor. Similarly, the findings imply that there is lack of guidance and counselling office in most of the colleges surveyed which makes it difficult for counsellors to operate effectively. According to Akinade, Sokan and Osarenren (2005), several factors such as increase in students' population and inadequate number of classroom result in the problem of pace or accommodation for counselling office. In discussing accommodation for counselling service, Oladele (2000) opined that space in which to carry out counselling services is very necessary yet it is the last unit to be provided. 
Lack of interest is one of the reasons for Student-teachers not patronizing guidance and counselling due to not having enough information on the benefit of guidance and counselling, hence the Student-teachers lack holistic development intellectually, emotionally, socially and psychologically. According to Nyarko-Sampson (2010), guidance and counselling service provides benefits to students by addressing their intellectual, emotional, social and psychological needs.

\subsection{Suggestion for the Effective Delivery of Guidance Services}

The findings in Table 3 revealed that majority of the respondents indicate the provision of guidance and counselling offices in Colleges of Education in Volta Region. This gives credence to Nyarko-Sampson (2010) and Sedofia (2011) recommendations that college authorities, as a matter of urgency, allocate offices or a permanent place for counselling purpose. Similarly, substantive number of Student-teachers suggested that counsellors must be confidential. This means counsellors should not disclose client's secrets to tutors or any other person to cater for confidentiality. This suggestion is in line with Akinade, Sokan and Osareren (1996) who stated that the nature of counselling is such that it requires client to reveal intimate feeling and thought that could be embarrassing or ruinous to them if revealed or made available to parties outside the counselling relationship. The need for confidentially is viewed as cornerstone of several professional psychology as such counselling is a one-to-one relationship and client-centred process that demands confidentiality (Gibson and Mitchel, 1990).

Similarly, most of the respondents suggested provision of qualified counsellors. This collaborates with NyarkoSampson's (2013) views that the 2002 Report of the President's

Committee on Review of Education Reform in Ghana recommended that each school should have trained guidance and counselling officer/teacher to offer counselling services to staff and students. However, creation of adequate awareness, provision of material resources employing techniques to arouse trainees' interest, allocation of adequate time for guidance and counselling activities were part of the suggestions.

\section{1. Conclusions}

The study concluded that;

1. Out of the eight guidance services investigated, orientation and counselling services were provided to large extent whilst consultation, information, evaluation, placement, appraisal and follow-up services were found to be provided to a lesser extent or not provided in some of the Colleges of Education.

2. There is lack of confidentiality, lack of office for the purpose of guidance and counselling activities and inadequate counsellors in the Colleges of Education in the Volta Region.

\subsection{Recommendations}

On the basis of the conclusion drawn from the key findings of the study, the following recommendations have been made:

1. College counsellors should be empowered by college authorities to organize other types of guidance services such as consultation, information, evaluation, placement, appraisal and follow up services through seminars, durbars and excursions in order to give due attention to those services on the college guidance and counselling calendar. When this is done it will help Student-teachers to overcome personal adjustment problems, economic problems and educational problem that they encounter through tertiary education and later in life.

2. The recruitment of high-level professional counsellors to the Colleges of Education so that their expertise would encourage patronage of guidance services. There should be the involvement of Non-Governmental Organizations assisting in the guidance and counselling programme in cash and kind to make guidance services more accessible and effective in the Colleges of Education in the Volta Region, Ghana.

\subsection{Counselling Implications}

The earlier researcher studies by Nyarko-Sampson, (2013), Sedofia and Ocansey (2013), Sedofia (2011), Mensah (2007), Aidoo (2011) (Nyarko-Sampson, 2010) exposed gaps.

Firstly, consultation services are not offered in the colleges of education contributed to Student-teachers not benefiting from the exchange of ideas among guidance functionaries. Also, the lack of information services denied Student-teachers the opportunity to have access to academic, vocational and personal information.

Furthermore, appraisal services, follow-up services and evaluation services which would determine the individuality, the progress Student-teachers and the effectiveness of the guidance and counselling programme respectively were not offered to Student-teachers. In as much as this present study cannot all this these pertinent issues it sought to narrow the gap by providing concrete information on the extent to which guidance services should be offered in the colleges of education. The current study suggested the following; 
Counsellors should include other guidance services apart from orientation and counselling in offeringguidanceservices for instance; Consultation service will help the counsellors to involved and exchange ideas among significant individuals such as teachers, parents, guardians, other guidance functionaries and agencies to help Student-teachers resolve their academic, career and socio-personal challenges. Information service would provide the opportunity to the counsellors to assist Student-teachers to understand, accept and utilize their abilities, aptitudes, interests and attitudinal patterns in relation to their aspirations in and after college. The purpose of placement is getting appropriate placements for Student-teachers on a programme of instruction or training scheme that is in line with their plans, aptitudes, attitudes, interests, and abilities if implemented effectively it will help develop Student-teachers holistically towards future life.

Appraisal service is mostly concerned with providing data that will highlight the individuality of each teachertrainee by comparing them with others in terms of quantities of general human characteristics this help the counsellor to cater for individual needs of Student-teachers. When follow-up service is offeredit will help the counsellor to monitor the progress of students who availed themselves for counselling within and out of college to determine the extent to which the Student-teachersbenefited from guidance services offered.

Evaluation service will help the counsellor to use scientific methods to find out whether the guidance and counselling programme is effectivein achieving its goals. When all the guidance services are implemented in the colleges of education it will promote guidance and counselling programme to meet the needs of Student-teachers and the society.

\section{References}

Ackom, P. E. (1992). Secondary school students' perception of guidance coordinators: A study in the Western Region of Ghana. Unpublished Master's Thesis, University of Cape Coast, CapeCoast, Ghana.

Akatsi College of Education (AKATSICO). (2014). Student registers for the 2014/2015 academic year. AKATSICO, Akatsi: Author.

Akinade, E. A., Sokan, B. O., \& Osarenren, N. (2005). An introduction to guidance and counselling, Ibadan: A basic text for College and University. Caltop Publication.

Akinade, E. A., Sokan, B. O., \& Osarenren, N. (1996).An introduction to guidance and counselling. Ibadan: Caltop Publication.

Ary, D., Jacobs, L. C., \& Sorensen, C. (2010).Introduction to research in education (8 $8^{\text {th }}$ ed.). Belmont, CA: Wadsworth.

Biswalo, P. M. (1996). Introduction to guidance and counselling in African setting. Dar-esSalaam: University Press.

Braimah, M. (2010).Assessment of guidance and counselling services in senior high schools in Tamale metropolis. Unpublished undergraduate research project,University of Education, Winneba: Ghana.

Dambai College of Education (DACE). (2014). Student registers for the 2014/2015 academic year. DACE, Dambai: Author.

Duku, E. K. (1991). Student's perceptions of the counselling services at the University of Cape Coast: Unpublished M.Ed. Thesis, University of Cape Coast, Cape Coast.

Eyo, M. B., Joshua, A. M., \&Esuong, A. E. (2010).Attitude of secondary school students towards guidance andcounselling services in Cross River State. Edo Journal of Counselling, 3(1), 87-99.

Farrant, J. S. (2004). Principles and practice of education. London: Longman Group UK Ltd.

Fia, S. D. (2008). An evaluation of counselling services as an intervention for school indiscipline $\quad$ in $\quad H o$ Municipality: Unpublished Master's Thesis, University of Education, Winneba.

Garba, A. (2013). Imperatives of programming in guidance and counselling in higher education. Keynote address presented on occasion of formal presentation ofbenchmark statements on student support services and guidelines on counsellingand Human Development Centres in Nigeria universities, organized by UniversityCommission (NUC), January 15, 2013.

Ghana Education Service (GES). (2003). Draft national guidance and counselling policy. Accra: Author.

Gibson, R. L., \& Mitchell, M. H. (1990). Introduction to counselling and guidance (3rded.). New York: Macmillan.

Gysbers, N. C., \& Henderson, P. (2001). Developing and managing your school guidance programme (3rd ed.). Alexandria, VA: American Counselling Association.

Gumisiriza, J. (2012). Orphan care organization. Abba home orphanage. Retrieved from: http://www.abbaorphancarepk.org.

Jasikan College of Education (JASICO). (2014). Student registers for the 2014/2015 academic year. JASICO, Jasikan: Author.

Kankam, G. A.,\&Onivehu, A. O. (2000).Principles and practice of guidance and counselling. Accra: KN AB Ltd. 
Kochhar, S.K. (2006). Educational and vocational guidance in secondary schools. New Delhi: Sterling Publishers Private Limited.

Leedy, D. L., \& Ormrod, J. E. (2005). Practical research: Planning and design. (8th ed.). Upper Saddle River, NJ: Merrill/Prentice Hall.

Lunenburg, F. C. (2010). School guidance and counselling services. Journal of Schooling, 1(1), 1-9.

Mensah, A. E. (2007). The place of guidance and counselling in teacher training colleges in the

Region of Ghana. Unpublished Master's Thesis, University of Education,Winneba, Ghana.

Numale, K. M. (2007). Guidance and counselling in education. Cape Coast: Yaci Publications.

Nyan, C. F. (2014). Students' and teachers' perception of guidance and counseling services. Unpublished master's thesis, Makerere University, Eastern, Uganda.

Nyarko-Sampson, E. (2010). Teacher trainees' appraisal of guidance and counselling programmes in colleges of education in Ghana: A study of selected colleges in the Eastern and Greater Accra zones. The Nigerian Journal of Guidance and Counselling 15(1), 95-110.

Nyarko-Sampson, E. (2013). Tutors' participation in guidance and counselling programmes in colleges of education in Northern Ghana. Ife Psychology GIA 21(2), 141-149.

Oladele, J. O. (2000). Guidance and counselling: A functional approach. Lagos: Johns-Lad Publisher Ltd.

Peki College of Education (GOVCO). (2014). Student registers for the 2014/2015 academic year. GOVCO, Peki: Author.

Sarantakos, S. (2005). Social research ( $3^{\text {rd }}$ ed.). Houndmils: Macmillan Press Ltd.

Sedofia, J. (2011). An evaluation of guidance and counselling programme in the Colleges of Education in the Volta Region of Ghana. Unpublished Master's Thesis Universityof Cape Coast, Cape Coast Ghana.

Sedofia, J., \&Ocansey, F. (2013). An evaluation of the information and consultation services in the colleges of education in the Volta Region of Ghana. Educational Research. 4(9), 674-681.

St. Francis' College of Education (FRANCO). (2014). Student registers for the 2014/2015 academic year. FRANCO, Hohoe: Author

St. Teresa College of Education (TERESCO). (2014). Student registers for the 2014/2015 academic year. TERESCO, Hohoe: Author

Taylor, A. I., \&Buku, D. K. (2006).Basics in guidance and counselling. Winneba: Department of Psychology and Education, University of Education.

Unachukwu, G. C.,\& Igborgbor, T. (1991). (Eds.) Guidance and counselling: A realistic approach. Nigeria International Universities Press.

Weiten, W. (2001). Psychology: Themes and variations (5thed.). USA: Thomson Learning Inc.

Williams, C. (2007). Research methods. Journal of Business and Economic Research, 5(3), 65-67. 